\title{
The End of Whiteness and the Rise of Multicultural Asian America in Chang-rae Lee's Aloft
}

DOI:

10.1353/jaas.2017.0035

Link to publication record in Manchester Research Explorer

\section{Citation for published version (APA):}

Raymundo, E. (2017). The End of Whiteness and the Rise of Multicultural Asian America in Chang-rae Lee's Aloft. Journal of Asian American Studies, 20(3), 441-459. https://doi.org/10.1353/jaas.2017.0035

\section{Published in:}

Journal of Asian American Studies

\section{Citing this paper}

Please note that where the full-text provided on Manchester Research Explorer is the Author Accepted Manuscript or Proof version this may differ from the final Published version. If citing, it is advised that you check and use the publisher's definitive version.

\section{General rights}

Copyright and moral rights for the publications made accessible in the Research Explorer are retained by the authors and/or other copyright owners and it is a condition of accessing publications that users recognise and abide by the legal requirements associated with these rights.

\section{Takedown policy}

If you believe that this document breaches copyright please refer to the University of Manchester's Takedown Procedures [http://man.ac.uk/04Y6Bo] or contact uml.scholarlycommunications@manchester.ac.uk providing relevant details, so we can investigate your claim.

\section{OPEN ACCESS}




\title{
THE END OF WHITENESS AND THE RISE OF MULTICULTURAL ASIAN AMERICA IN CHANG-RAE LEE'S ALOFT
}

\author{
Emily Raymundo
}

\begin{abstract}
This article reads Chang-rae Lee's Aloft (2004) for what it reveals about how literature is used by neoliberal multiculturalism to recruit subjects into its rationale, highlighting the problems that multiculturalism generates for Asian American studies scholars. Aloft uses its white male protagonist to launch a cogent critique of whiteness, revealing how whiteness constructs itself as an invisible norm against which all difference emerges as abnormal and aberrant. Yet even as the novel critiques whiteness, Aloft also envisions a multicultural future in which the structures of privilege that once defined whiteness are not abandoned or dismantled; rather, they are inherited by Paul Pyun, Jerry's Korean American son-in-law. These two facets of the novel are not in conflict-they do not contradict each other, but rather work in tandem to unfold a multicultural vision of privilege, flexibility, worthiness, and dignity that appears to resolve the problems of racial difference while actually cutting racial formations along new lines. Aloft then demonstrates the ways in which trenchant critiques of whiteness, Orientalism, and racialized exploitation can travel alongside, and even enable, narratives of multicultural ascension.
\end{abstract}

hang-rae Lee's 2004 novel Aloft opens with Italian-American protagonist Jerry Battle surveying his suburban Long Island neighborhood from the comfort of his private seaplane. "From up here," the novel begins, "a half mile above Earth, everything looks perfect to me." A few pages later, Jerry flies over his own house, noting that the house is "forever unmistakable" because he "had a roofing contractor lay in slightly darker-shaded shingles in the form of a wide, squat X." This mark, he explains, was for the benefit of his ex-girlfriend Rita, "for she always asked me to point out our place from the air, which I did but to no use, as she could never quite find it anyway." Despite the fact that the " $x$ " did not have its intended effect for Rita, Jerry 
adds, "I must say the sight still always warms me, not just for the raw-meat feeling that l've marked my spot, but for the idea that anyone flying or ballooning overhead might just wonder who was doing such a thing, this mystery man calling out from deep in the suburban wood."1

This opening passage sets the stage for the novel's central concerns. Jerry's solo flight above his neighborhood, his continued emphasis on his lofty perspective (compounded, of course, by the title), suggests that in Aloft, location-both social and spatial - is everything. The opening metaphor - the house with the " $x$ " — reveals that the novel hinges on schematics, emotional and visual, that are hidden in plain sight. What should be easily visible and identifiable is somehow difficult to see, requiring excess signification in order to be legible. At the same time, what is valuable for its sameness to its surroundings at one perspective (at ground level, suburban homes are created to look the same) must be made visibly different at another level for recognition. Yet even from a similar vantage point, visibility and recognition hinges on not only spatial location but also gendered social orientations, as Rita - a Puerto Rican woman, and one woman of color in a series of women of color that take up the seat next to Jerry throughout the novel-never recognizes the house even with the $x$, while Jerry not only recognizes it visually, but feels a deeply gendered resonance with it, imagining himself a "mystery man calling out from the deep." ${ }^{2}$ Here too, the novel hints at one of its central tropes: the disenchanted, suburban white man plagued with ennui, searching for a more visceral connection than the one afforded him by his privileged lifestyle. In a twenty-first-century twist, Jerry's ennui is not resolved by forming a sexual connection with a younger white woman or even by reinvigorating his status as patriarch; Jerry is instead rejuvenated through his connection to his Korean American son-in-law, Paul Pyun.

While this complex opening metaphor hints at what the novel will be about, it also lays out a schematic for how the novel should be read. Its multiple vantage points, which operate simultaneously, remind the reader of their own vantage point over the narrative-one which seems omniscient, but which, the only-sometimes-visible $x$ on the house suggests, can easily miss or misrecognize seemingly obvious cues. This narrative alienation, which is quite subtle, might easily be chalked up to an everyday feature of postmodern literature. Instead, I argue that Aloft's invocation of the instability and multiplicity of social positions and their respective orientations is specific to, and revealing of, the novel's own position as a representative example of minority culture in a neoliberal multicultural market.

In this article, I read Lee's Aloft for what it reveals about how literature is used by neoliberal multiculturalism to recruit subjects into its rationale. 
Neoliberal multiculturalism, a term I borrow from Jodi Melamed, is a cultural ideology, an economic structure, and a "global racial formation," one that emerged in response to, first, the "racial break" instantiated by the civil rights movement, in which the U.S. state moved from governing through overt white supremacy to governing through formal racial equality, and, second, the globalization of capital. ${ }^{3}$ Developed in part to manage and contain the radical challenges posed by the civil rights movement and the Third World strikes of 1968, multiculturalism flexibly absorbs the language, tropes, and demands of racial justice activism and adapts them for its own purposes. And where older formations of liberalism depended on cultural tropes of universalism to recruit subjects-using culture to foment fables of national homogeneity and unity and cover over inconvenient differences-neoliberal multiculturalism deploys heterogeneity, fragmentation, and the proliferation of difference to expand the reach of markets and perfect its strategies of governance. Rather than seeking to exclude minority writers from an elite literary canon, for example, multiculturalism exalts the canonizing of specific minority writers and champions the transformation of minority literatures into markets, so long as such changes are aesthetic, not structural. At its heart, neoliberal multiculturalism is an "official antiracism" that nonetheless depends on racial difference in order to do its economic and institutional work. ${ }^{4}$

I argue that Aloft reveals these racial operations of multicultural neoliberalism, and simultaneously, highlights the problems that multiculturalism generates for ethnic and American studies-based cultural studies scholars, and in this case, specifically Asian American studies scholars. That is, Aloft recognizably traffics in tropes of racialized alienation, exclusion, and in/ visibility, all of which have regularly been read as central to Asian American literature. Aloft uses its white male protagonist to launch a cogent critique of whiteness, revealing both how whiteness constructs itself as an invisible norm against which all difference emerges as abnormal and aberrant, and how whiteness is embedded in long material histories of exploiting and alienating the "others" it creates. These critiques align with, and are legible through, the interpretive schemas of Asian American literary studies, which often read Asian American literature for the ways it exposes and critiques these racializing processes.

Yet even as the novel critiques whiteness, Aloft also envisions a multicultural future in which the structures of privilege that once defined whiteness are not abandoned or dismantled; rather, they are inherited by Paul Pyun, Jerry's Korean American son-in-law. These two facets of the novel are not in conflict-they do not contradict each other, but rather work in tandem to unfold a multicultural vision of privilege, flexibility, worthiness, 
and dignity that appears to resolve the problems of racial difference while actually cutting racial formations along new lines. As Paul Pyun is folded into Jerry's social position, that is, his acceptance is contingent on the deaths of the two Korean American women in the text; as new vectors of multicultural value overlay and splinter off from older social schemas, some Asian Americans are folded into the structure of privilege called whiteness, while others, particularly women, are cleaved definitively out of that structure. Aloft then demonstrates the ways in which trenchant critiques of whiteness, Orientalism, and racialized exploitation can travel alongside, and even enable, narratives of multicultural ascension.

In order to trace these overlaid and entangled racial formations in the text, I draw on Raymond Williams's conception of the interplay between emergent, dominant, and residual cultural formations. ${ }^{5}$ Williams argues that it remains an "open question" as to how social structures like racial formations relay between conscious choices, seemingly fixed and stable unconscious fact, and embryonic and emergent nonconscious feelings. Race, as a relation of social difference, is not fixed; rather, it is a dynamic form whose relationships to both past and present are not necessarily predetermined or predictable. A text may be read within the cultural tropes, linguistic markers, and stylistic aesthetics of a dominant racial formation, but it also contains traces of emergent racial formations, which may not have crystallized into recognizable categories or cultural idioms but nonetheless exert material and affective force on the everyday, lived experience of race. In other words, Aloft's characters enter the novel with bodies and subjectivities that map fairly neatly onto sedimented and dominant racial categories, but as the novel progresses, privilege, power, and social locations are redistributed, shifting the material grounds upon which race is determined and enforced. Aloft's capacity to traffic in both memories of Asian America's traumatic past and dreams of Asian America's multicultural future illuminates a new formation and function of race within neoliberal culture and global capital.

\section{On the Multicultural Market}

Within the confines of the multicultural market, where the racial identity of an author or characters is leveraged to sell a book to racialized audiences, the "racial asymmetry" between Chang-rae Lee, a Korean American who immigrated to the United States as a child, and his narrator Jerry Battle, an Italian American whose family has been embedded in the fabric of New Jersey suburban life for at least two generations, has generated anxiety for Aloft's critics. ${ }^{6}$ Mainstream book reviewers lauded Lee's "expansive 
spirit" and range as an author, while simultaneously worrying that Lee's authorial voice rang false: Jerry's narration is "awkwardly filtered" through "self-consciously lovely writing-school language," and sounds less like"the voice of the 60-year-old stiff who took over Battle Brothers Brick \& Mortar" and more like "a 38-year-old graduate of Phillips Exeter Academy and Yale University."7 Lee's prior marking, and marketing, as an ethnic author meant reviewers seemed obliged to frame Aloft as being about race or ethnicity, characterizing the novel as an "immigrant story" that "approaches the problems of race and belonging in America from a new angle." ${ }^{\prime 8}$ These anxious vacillations between praising the novel's seemingly universal appeal and demarcating its ethnic particularities-Asian American author, Italian American protagonist-reveal the multiple burdens upon, and functions of, minority culture within neoliberal multiculturalism. On the one hand, the demand for "universalism," and the implicit collapse of whiteness with universalism, generated by older forms of liberalism, has not yet receded. Yet on the other, multiculturalism also generates new demands on culture; rather than aspiring to universalism, multiculturalism deploys racial difference, here visible as a repetitive invocation of Lee's Asian Americanness as central to his authorial brand, in order to justify itself as an equitable, enlightened social schema and expand its market reach.

In her landmark text Immigrant Acts, Lisa Lowe argued that Asian American culture was formed within and by American national culture, even as it produces alternative meanings and cultural forms. For Lowe and her contemporaries, American national culture ideally functions to cover over capitalism's inevitable material inequities through abstraction; that is, national culture allows materially differentiated subjects to reunite on the ground of the imagined nation as abstract, formally equal citizens. ${ }^{9}$ This cultural abstraction is a racializing mechanism; the nonwhite, female, disabled, indigenous, and indigent subjects who were legally barred from citizenship were also never sufficiently universal to be fully abstracted into cultural citizenship. ${ }^{10}$ Asian American literature works against this universalizing imperative by refusing to obscure the history and present of those material differences-in short, by retaining its material difference rather than allowing it to be abstracted. ${ }^{11}$

Lowe's formulation of Asian American culture as a space of contradiction within the intertwining of national culture and capitalism remains essential to understanding the workings of Asian American culture today. However, Lowe's description of how culture and capital work to produce national citizens (and thus consumers) is focused on a liberal formation of nation-state and national capital. Yet the transition from Fordism and the trade of national resources to the mode of capital variously called trans- 
national, global, or flexible accumulation has fundamentally changed not only the organization of capital but also the modes of social organization that capital creates, maintains, and depends upon. As such, literature and other forms of national culture also function differently within a system of capital that is organized globally rather than anchored through the nationstate, and that depends on differentiation, proliferation, consumption, and commodification rather than regulation, production, and stability. ${ }^{12}$

As Grace Hong points out, this shift in the relationship between national culture and capital has particular effects for the effect and function of race within culture: "Global capital reproduces itself exactly by manipulating racial, gender, and sexual difference for the purposes of accumulation. In other words, if 'Asian American' or 'Chicano' or 'African American' are categories that assert racialized subjectivity as a critique of white supremacy and the corresponding logic of assimilation, they are now equally ways of identifying and producing consumer bases, or alternatively, pools of exploitable labor."13 For Hong and other scholars of late global capitalism, universalized, homogenous citizenship is no longer the subject formation used to discipline and recruit worker-citizens. Rather, that discipline takes place through the commodification of difference, as racialized and gendered identity categories become markets of targeted production and consumption, wherein "consumerism and commodification ... instantiate a new form of universality." ${ }^{14}$ Thus, national culture no longer needs to suture together citizens through a collective imaginary of assimilated and homogenized behavior. Instead, culture can function to further particularize and differentiate populations in the name of creating new consumer markets and creating and maintaining exploitable populations at the same time.

In addition, because multiculturalism is in part a reaction formation to the U.S. civil rights movement and the following "racial break" in state governance, it is remarkably_and dangerously_adept at absorbing critiques aimed at lessening racial disparities. Neoliberal multiculturalism consists of a number of technologies and governance tactics that function to stabilize this global racial formation, including (1) substituting "aesthetic and cultural representation" for political representation, so that it is now common sense that equalizing cultural representation (e.g., equalizing the number of Asian American actors in Hollywood films) will translate into equalized political and economic conditions; (2) selectively incorporating elite individuals from oppressed classes or peoples into visible positions of power based on their worth within "neoliberal circuits of value," such as their ability to prove themselves "flexible," "rational," "feminist," and "law-abiding"; (3) commodifying and proliferating social identities, includ- 
ing racial, gender, sexual, and subcultural identities, in order to expand economic markets and guarantee full participation in those markets; and (4) promoting the previous three technologies as the result of a successful state-led campaign to end racism (and, similarly, misogyny and homophobia) that then justifies the United States' military and economic intervention into states and governments deemed insufficiently multicultural, feminist, gay-friendly, and so on. ${ }^{15}$ The net effect of these strategies is that older racial formations, which emerged in relation to an overtly white supremacist U.S. state, are not resolved by multiculturalism; rather, they are stabilized, and often, exacerbated. At the same time, new racial cleavages and formations are emergent in relation to neoliberal multiculturalism, premised on its new schema of worth and dignity, which both overlay older formations and cut new schisms through racialized populations.

Visible and aesthetic racial difference within multiculturalism, then, does not rupture a national aesthetic imaginary, but rather functions in the service of that imaginary to cover over both entrenched and newly emergent material differences. Even aesthetic and affective references to the violent and traumatic history that formed recognizable racial differences can be made without disturbance to multiculturalism's vision of the racial present and future, as long as the relationship to that past history is figured as aesthetically and affectively resolved.

Aloft portrays, quite self-consciously, a long history of racialized material difference, as wealthy white protagonist Jerry Battle repeatedly meditates on his own racial identity and its material and historical formation while all around him, to put it bluntly, Asian and Asian American women drop like flies. Yet despite the novel's insistent engagement with the production of whiteness and race as a relation of difference, Aloft's tone is one of orientation and resolution, as Asian American and white men are aligned and oriented toward a global future wherein whiteness is replaced with "multicultural" privilege. While Aloft's present is certainly haunted by the traumatic racial past, that past is resolved by the end of the novel. Indeed, the multicultural future that Aloft suggests in its closing pages is exactly one in which the traumatic relationship to the past is finally overcome. Aloft definitively critiques the abstraction of whiteness, as predicated on the violent exclusion of Asian Americans; yet when close attention is paid to the dynamism and deviousness of racial categories, a different vision of Asian American identity emerges - one capable of remaining aesthetically distinct from whiteness and yet being folded into the category of power once called "whiteness." 


\section{The End of Whiteness?}

Prior readings of Aloft have exposed the ways in which the novel works to critique, and even undo, whiteness's worlding power. The novel is populated with winking references to recognizable symbols of the American dream, which is always predicated on unspoken exclusions: Jerry's suburban home, symbolic in and of itself, is also located in the "middle of the middle part" of Long Island, which, as Stephen Sohn points out, places it in or nearby the original Levittown, the first racially exclusionary suburbs of the nation; Jerry's former wife is also named Daisy, invoking The Great Gatsby's more famous Daisy from Long Island, yet another symbol of an American dream promised to all but extended to only a few. Noting that almost every character except Jerry is nonwhite, Mark C. Jerng argues that by viewing the racialized world through Jerry's ostensibly universal gaze, Aloft renders Jerry's whiteness visible. In this reading, Lee deploys Jerry's whiteness not just to particularize it by revealing the way whiteness coheres only in relation to other racial categories, but also to critique a specific liberal, multicultural mode of perceiving race, one that admits aesthetic racial difference and yet denies it any material effects. ${ }^{16}$

To destabilize Jerry's refusal to acknowledge the material effects of race, Aloft would have to reveal those effects elsewhere in the text. Stephen Sohn takes up this aspect as he focuses on Daisy, Jerry's first wife and a Korean immigrant who commits suicide in the house's pool before the novel begins. Sohn reads Daisy's performance of toxic domesticity as motivated not by biological illness but by the social "madness" generated by pressures to assimilate into an unwelcoming culture. Jerng and Sohn's readings collide at the end of the novel, as the racialized trauma that Daisy's death embodies finally proves to be so devastating — so disorganizing - that Jerry's universalized position is not merely shaken but shattered. Only after Jerry faces the truth of Daisy's suicide-represented by him finally re-excavating the pool for his grandchildren to use-and begins the painful process of actually facing the trauma of her death can his family be reconstituted and the home be remade.

Notably, however, the home is finally remade without Jerry in it. Though he began the novel flying "a half mile above Earth," Jerry ends the novel in the hole in the ground that once was the pool, as his reconstituted family proceeds without him: "Now where's Jerry? somebody says, the barely audible sound traveling just above and far enough away from me that I don't immediately answer. It's okay. No problem. They'll start without me, you'll see." ${ }^{17}$ Jerry's prophecy that the family will carry on without him heralds the disappearance of the white patriarch, as family head, as univer- 
salized narrator, and, importantly, as the idealized national citizen that the reader can or should identify with. It might even, in fact, signal the disappearance of whiteness itself, as the fantasy of the centrality of whiteness to normative social life is interrupted, permanently. Simultaneously, the fantasy of the suburbs themselves in the end comes closer to approximating the demographics of the suburbs in the twenty-first century: as Karen Tongson points out, the suburbs today "have been globally restructured, reconstituted as service economies, and repopulated as residential apartment communities for low-wage immigrant workers reliant on service sectors for sustenance."18 Thus Lee also dispels the myth of the suburbs as a haven for white normativity, and instead portrays them, finally, as a place where nonnormative, multicultural families can flourish.

But if the novel unearths the traumatic histories of exclusion from the nation suffered by Asian Americans, and of deploying those histories to interrupt the fantasies of universality and white normativity, why then does it feel so, well, resolved? That is, despite the very clear ways Aloft critiques the organizing power of whiteness, its tone-what Sianne Ngai defines as "an affective-aesthetic idea ... which is reducible neither to the emotional response a text solicits from its reader nor to representations of feelings within the world of its story," but is instead "a literary text's affective bearing, orientation, or 'set toward' its audience and world" —would be difficult to call disorganizing. ${ }^{19}$ Instead, the novel is very clearly oriented toward a specific future-one in which, yes, the white patriarch might have disappeared, but the structures of privilege that once enshrined him, though expanded, remain intact. The family, after all, has not dissolved but been reconstituted; the suburbs, too, have been renewed; the organizing, worlding power of the white patriarch has been conceded-but to whom?

Rather than opening the possibility of a world without whiteness-or at least a world that is not worlded through whiteness-Aloft instead opens the possibility that some Asian American bodies might come to extend or inhabit the space of privilege formerly called whiteness; rather than dispelling the power of whiteness, Aloft merely extends its boundaries while reinforcing the structures of privilege that enabled whiteness in the first place. The world can go on without Jerry-but not because it does not need a man like him anymore, but because Paul Pyun, his Korean American son-in-law, has taken his place.

Jerng and Sohn's readings rest on the assumption that "race," and the accompanying power structures that make race legible and meaningful, are fixed to the bodies of the characters as they enter the novel. Arun Saldanha, however, reading a famous passage in Frantz Fanon's The Wretched of the Earth, argues that race is not just a fixed self/other dialectic, but rather a 
way of describing "how certain bodies stick to certain spaces, how they are chained by hunger, cold, darkness, mud, poverty, crime, glances full of envy and anxiety." ${ }^{20}$ Race does not inhere in bodies but instead congeals and operates through bodily relations, not only between bodies, but also between bodies, objects, and the spaces that surround them. Saldanha adds, "Race is devious in inventing new ways of chaining bodies. Race is creative, constantly morphing. ... What defines races is not rigidity or inevitability, but its 'lines of flight.'" As Nikhil Singh points out, racial categories are always dynamic and in flux; often, what we might describe as a relation of "race," a relation of differentiation, disparity, vulnerability, or violence, occurs "in advance of stable orders of racial reference and in contexts in which fields of racial reference are actively destabilized."21

To assume that because Jerry, as the signifier of hegemonic albeit uneasy whiteness, is no longer in the picture, whiteness is no longer in the picture is "based on the unexamined premise that whiteness is a fixed racial category." 22 Like any other racial signifier or structure, whiteness is not necessarily a fixed property of the body. Matthew Frye Jacobson argues that historians of race have, in freezing whiteness as a social category, missed what he calls the "vicissitudes of whiteness"; he argues that whiteness, like any other racial formation, is a contested category that has been subject to challenges, consolidations, and corrections throughout its history. ${ }^{23}$ Just like "Asian American," "whiteness" is a racial category that coheres a specific assemblage of structural relationships and feelings that distribute value, privilege, and life chances throughout a population. Sara Ahmed calls this an "orientation": "Whiteness is lived as a background to experience ... which orientates bodies in specific directions, affecting how they 'take up' space ... which in turn shapes what bodies 'can do.'"24 What is called "whiteness" within our current racial order is actually a structure of social relations, not only between people, but also between bodies and the spaces and objects that surround them; "white" bodies are those that seem to "belong" in public spaces, for instance, while nonwhite bodies are those that are viewed with suspicion, judgment, and fear in the same space.

When understood as an orientation rather than a property of specific bodies, "whiteness" can be assumed by bodies that do not appear to us as "white." This flexibility is a signature innovation of neoliberal multiculturalism: "As economic citizenship becomes more central to racial procedures and while whiteness as property is still operational, globalization also creates multicultural as a new form of whiteness, or rather the category of whiteness and its privileges are sublated into the category of multiculturalism." 25 "Multiculturalism," that is, is a new name for an expanded version of the structural privilege and power once called "white supremacy." While 
it signifies as "the end of whiteness," multiculturalism in fact extends the worlding power of whiteness by extending its reach. ${ }^{26}$

Read with an understanding of whiteness as orientation, Aloft is still oppositional to a white supremacy-based cultural project of abstraction and universalism. Yet, simultaneously, Aloft collaborates with the dictates of multiculturalism, which expands the category of whiteness as orientation to include some-but certainly not all-nonwhite subjects. In particular, Paul Pyun, the Korean American fiancé of Jerry and Daisy's daughter Theresa, comes to signify the multicultural subject capable and worthy of being incorporated into the privileges of whiteness. Like Daisy, Theresa dies in an overdetermined location, the cockpit of her father's plane; like Daisy, her death is at least partially driven by her own toxic performance of gendered roles, as she refuses to seek treatment for her fatal cancer in order to carry her child to term. Through their affective experiences of and responses to loss, the novel aligns Paul and Jerry, positioning Paul not just as Jerry's worthy successor but, in fact, as more worthy than Jerry of the privileges he assumes. Jerry and Paul's affective kinship, which initially coheres as a product of racial difference, is transformed throughout the course of the novel to a structure of shared racial feeling, predicated on the shared ability to escape trauma and to survive (and flourish) in the symbolic space of the suburban home. The novel's tone, one of resolution and orientation rather than fragmentation and disorientation, does not stem from the racial feelings that generate and are generated by Daisy and Jerry's relationship, which cohere in an older structure of Orientalism and white supremacy. Instead, they stem exactly from Jerry and Paul's shared structure of racial feeling, which coheres within the emergent racial categories of multiculturalism.

Certainly, Paul enters the text as an already-given ethnic body-he's introduced to the audience by Jerry musing, "I guess if you put a gun to my head l'd say he writes about The Problem of Being Sort of Himself-namely, the terribly conflicted and complicated state of being Asian and American and thoughtful and male." ${ }^{27}$ Unsurprisingly, this characterization has led reviewers to read Paul as Chang-rae Lee's avatar in the text. Here, reviewers' anxiety that Jerry sounds "too much" like Chang-rae Lee is assuaged by confirming that Chang-rae Lee's voice-and body-can be located elsewhere in the text, outside of and separate from Jerry, in a character who is more "like" him. ${ }^{28}$ The metaphor of familial "likeness" as it applies to race - in that all members of a racial category are said to be "like" one another, in ways that they are not "like" members of other races-is one effect of presuming that race is a static or fixed characteristic. Yet if race in general, and whiteness in specific, is an orientation - a specific way of facing 
the world, as well as a force that organizes which objects and spaces unfold for a subject and how they do so-then who is "alike," aesthetically, is less material than who is aligned, that is, who faces the world in the same way.

Despite Jerry's conscious differentiation between himself and Paul, which rely on assumptions about racial un/likeness ("He's not like me at all ... we come from dissimilar peoples and times and traditions and hold nearly opposite views on politics and the world"), he nonetheless feels an affective connection with Paul that extends beyond their racial difference. ${ }^{29}$ Although he is drawn to Paul initially because of his racial difference-just as he is to Daisy and his Puerto Rican girlfriend Rita-his interest actually extends beyond this, toward recognition of a shared social consciousness. He offers empathy to Paul that he is unable to offer to either Daisy or Rita, coding Paul's struggles with writing as a universal condition that also afflicts Jerry: "But that's the case with almost everyone in the broadening swath of middle age, isn't it, that we're all fatiguing in some critical way?"30 Jerry later confesses, "Paul is one of the few people who can always draw me out."131

This striking affinity with Paul, marked by their ability to communicate, stands in contrast to Jerry's relationships with Daisy, Rita, and Theresa, all of which are marked by refusals to speak and the inability to communicate properly. Jerry often remarks on Daisy's inability to speak grammatically correct English, particularly when she's upset, and he concludes a long section on Theresa's tendency to correct his word choices by saying, "This jibes with my own sharpening feeling that I can hardly understand anybody anymore." Paul, too, has trouble communicating with Theresa, as he confesses to Jerry after they've moved in to the latter's house: "'But you know what, Jerry? She might be right about our communication.' 'What the hell are you talking about? All you two do is talk.' 'Yeah,' he said wearily.... 'But maybe not in any way that counts."'32 Paul and Jerry's ability to understand each other - to speak each other's language - and inability to understand or speak to others traverses pregiven racial categories, as Paul's fractures his relationship with Theresa (despite their racial "likeness") while Jerry's cements his "difference" from Daisy and his daughter.

This kinship through shared language is certainly gendered, and could merely be read as two men bonding over their difficult relationships to women. Yet the racial implications of this kinship are affirmed at Theresa's funeral. Paul attempts to deliver a eulogy for his wife, but is unable to. Thus, Jerry delivers Paul's eulogy rather than reciting his own: "It was beautifully somber, serious, elegantly lyrical stuff ... and even though they knew it had been written by Paul a number of people complimented me on the moving, heartrending words." ${ }^{13}$ Ahmed suggests that whiteness, in its invisibility and presumed presence, is "what lags behind": "White bodies 
are habitual insofar as they 'trail behind' actions: they do not get 'stressed' in their encounters with objects or others, as their white-ness 'goes unnoticed.' ... When bodies 'lag behind,' then they extend their reach." ${ }^{\prime 34} \mathrm{~A}$ body's ability to "lag behind" and go unnoticed is what secures its ability to extend and reach beyond itself, so that what a white body can do appears to be what "any body" can do. But at the funeral, when Jerry reads Paul's words, it is in fact Paul's body that lags behind, such that even when people know that Paul wrote the speech, it appears as though the words and sentiments are Jerry's. In effect, Paul's body lags behind so that his reach may extend; Paul's mourning, not Jerry's, becomes the universal language of mourning, through which all mourners present can experience their own grief. In this instance, universality as a mode of identification is not so much disturbed as it is expanded, so that it can issue forth from Paul's body as well as Jerry's.

Thus, though Paul entered the text fixedly and consciously different from Jerry, the mourning of Theresa's death—and Daisy's death, before her-allows Paul and Jerry to align, and thus to figure as extensions of each other. The loss of a wife, the resultant future of raising children alone, and both men's repressed guilt that they might have caused their wives' deaths (Jerry through mishandling Daisy's mental illness, Paul by impregnating his wife, which led her to decline to seek treatment for her sickness) unite Paul and Jerry through a shared experience, a shared and inherited past that organizes their worlds into likeness.

However, it is not merely their shared, masculine experience that makes Paul worthy, or capable, of inhabiting and extending Jerry's racial orientation. Importantly, Jerry's defining characteristic throughout the novel, by his own admission, is his capacity for flight-that is, his desire and ability to detach from the traumatic present, as manifested in his constant romanticization "of perfect continuous travel ... the pleasures found not in singular marvels of any destination but in the constancy of serial arrivals and departures." ${ }^{135}$ Jerry declares, in the face of Daisy's death, Rita's leaving him, and Theresa's illness, "Jerry Battle hereby declines the Real." ${ }^{\prime 36}$ This flight from trauma, even as it plays out in front of him, is explicitly connected to his whiteness:

For if you took an accounting of all who proceed us, our alive and semi-alive relations from Forest Hills to Thousand Oaks to Amelia Island and to everywhere else they've rooted themselves with a vengeance, you'd have some kind of portfolio of golden twentiethcentury self-made American living, all those spic-and-span houses and Gunite pools and porcelain- and crystal-filled curio cabinets and 
full-mouth braces for the kids and the double wall ovens set on timers to bring the roast rosemary chicken and casserole of sweet-sausage lasagna to just the right crisp on top as Dad pulled the white Lincoln up the driveway, their contribution to our Great Society being the straight full trickle-down to my generation of Battaglias and Battles and Battapaglias and the rest of us with the sweetheart deal of a Set-It-and-Forget-It existence. Like everybody halfway decent and useful I of course recognize that one's character should rightly derive from privation, crucibles, pains in the ass, so I guess my only semirhetorical question is from what else does it come, if there's always been a steady wind at your back, a full buffet at your table, and the always cosseted parachuted airbagged feeling of your bubbleness, which can never brook a real fear? ${ }^{37}$

Jerry's inability to "brook a real fear" derives in his own estimation exactly from the comfort afforded him by whiteness (shored up, of course, by the class privilege that white suburban life affords him). Here, we can see what Sara Ahmed means when she explains that "in the case of race, we would say that bodies come to be seen as 'alike', as for instance 'sharing whiteness' as a 'characteristic,' as an effect of such proximities, where certain 'things' are already 'in place."'38 According to Jerry, the domestic markers of white suburban life-pools, curio cabinets, braces, lasagna-cluster around "Battaglias and Battles and Battapaglias," both the cause and effect of "golden twentieth-century self-made American living." Similarly, these "creature comforts," which are already in Jerry's reach, are precisely the things that keep him out of reach of trauma, such that he can witness it but not experience it viscerally himself.

Thus, the two symbols that the novel opens with-the plane and the suburban home-unite to perfectly describe whiteness as orientation, where the security of a stabilized position of social value enables social mobility and the capacity to escape trauma. The "spic-and-span house" and Jerry's "private box seat in the world and completely outside of it, too," are contiguous spaces that work together to organize and unfold the world for Jerry. Tellingly, when Jerry cedes his space in the home to take up his place in the earth, Paul takes Jerry's place in the master bedroom. Paul's gendered access to a shared, masculine language is then cemented by his physical presence in Jerry's racialized spaces; his access, then, is dictated not just by his masculinity but by the entanglement of his racial and gendered identity. Just as tellingly, Daisy dies at the house, and Theresa dies in the plane. 
Jodi Melamed argues that neoliberal racialization does not merely create new racial categories and structures but can also reinscribe older forms, "intensify[ing] technologies for disqualifying, civilizing, and disciplining people of color without class privilege, renewing older racial schemas." ${ }^{19}$ Daisy and Theresa prove incapable-and therefore unworthy, or vice versa - of sustaining their lives within the contiguous spaces of the suburban home and the plane. Their incapacity is marked in the body, as Daisy's mental illness and Theresa's cancer are the ostensible causes of their deaths. Those bodily traumas are themselves markers of inherited racial trauma (before she dies, Theresa confesses that she has known all along that Daisy killed herself), and simultaneously, the very vulnerability of their bodies to trauma is itself racialized. And of course, their bodies, and bodily traumas, are not just raced but gendered-like Daisy's toxic domesticity, the intensification of Theresa's illness is marked by Theresa's increasingly pathological attempts to fulfill the role of the "good mother," as she sacrifices the health of her own body for the health of her unborn child.

As Melamed and Grace Hong both point out, women of color and racialized immigrant women are often drawn outside the bounds of "neoliberal subjectivity and its moral calculus." ${ }^{40}$ As the new social relations of production created by multicultural neoliberalism both cut across and reinscribe existing racial categories, "terms of privilege accrue to individuals and groups, such as multicultural, reasonable, feminist, and law-abiding, that make them appear fit for neoliberal subjectivity, while others are stigmatized as monocultural, irrational, regressive, patriarchal, or criminal and ruled out." ${ }^{41}$ Women of color and racialized immigrant women are more susceptible to these accrued terms of stigmatization because they are often already coded as irrational and regressive, and are more vulnerable to the material conditions of exploitation that produce subjects as "monocultural," "patriarchal," or "criminal." Within a multiculturalist framework, Daisy and Theresa are characterized as irrational not because their racial and gendered difference renders them unable to conform to a specific mode of (white) middle-class normativity, but because their attempts to conform appear irrational within a world order in which race as aesthetics (determined by established racial categories) is not necessarily connected to race as a differential relation of material conditions (determined by both established racial categories and emergent racial procedures). Their unworthiness for multicultural subjectivity, like a Möbius strip, appears complex, but in fact only has one side that feeds into itself in a twisted loop: they cannot survive because their bodies are unfit; their bodies are unfit because they bear marks of gendered and racialized trauma; they 
bear marks of gendered and racialized trauma because their bodies are unfit; their bodies are unfit because they cannot survive.

In contrast, Paul's defining characteristic-“You don't have to sugarcoat it, Jerry. I know I'm a pushover" - is actually what proves him worthy for multicultural subjectivity, as it allows him to adapt to the cocoon of the suburban home without significant trouble. ${ }^{42}$ By the end of Theresa's illness, Paul has given up writing entirely, concentrating on caring for his wife, and, after her death, he is "ensconced in the master bedroom" according to "the all-agreed-upon-plan." And the alignment — the family line-of course does not end with Paul, but is continued by Paul and Theresa's child, Barthes Taejon Battle, whose face, Jerry notes, "is distinctively un-Caucasian"; in fact, not only does the child not look anything like Jerry, "which is how it has to be," but, he notes, "I can't quite see his mother in him either, not yet, as he is an exact replica of the infant Paul's parents have shown us in pictures from his baby album. ${ }^{\prime \prime 3}$ As Paul and Barthes take residency in the master bedroom of the suburban house-not quite the plane, but still "inside the world and outside of it, too" - their "un-Caucasian" appearance signals the flowering of a multicultural, antiracist world, but at the cost not only of Theresa's life but also her presence in the family line. Whiteness is both extinguished and extended, as racial categories are cleaved apart and cut deeper along gendered lines simultaneously.

Asian American critics are right to read Aloft as not only interrupting the universality of whiteness but also imagining its end. To stop at affirming Aloft's critique of whiteness, however, misses the way the text, and minority literature as a genre at large, can and does collaborate with multicultural neoliberalism. In fact, Aloft's capacity to be read as antiracist within a discourse of white supremacy and Orientalism is exactly the characteristic that covers over, and thus enables, its cooperation with the racial orders of global capitalism. The use of a critique of one racial order to give substance to a different racial order is a signature technology of multiculturalism, and it highlights the need for Asian American literary studies scholars, and ethnic studies scholars at large, to remain attentive to those racial formations and relations that are not yet fully articulated but nonetheless saturate the present and shape the future.

\section{Acknowledgments}

This article was initially presented at the Association of Asian American Studies Conference in Seattle in 2012, and has seen many iterations. Thanks to Joe Bernardo and Nic Ramos for organizing the initial panel; to John 
Carlos Rowe, Viet Thanh Nguyen, Jack Halberstam, and Chandan Reddy for incisive comments on early drafts; to Jessica Lovaas, who shepherded me through two major revisions; and to the reviewers at JAAS, as well as Winona Landis and Anita Mannur, for their labor, time, and support.

\section{Notes}

1. Chang-Rae Lee, Aloft (New York: Riverhead Books, 2004), 22.

2. Ibid.

3. Melamed draws her formulation of the "racial break" from Omi and Winant's formulation of post-civil rights racial formation. Michael Omi and Howard Winant, Racial Formation in the United States, 3rd ed. (New York: Routledge, 2014).

4. Jodi Melamed, Represent and Destroy: Rationalizing Violence in the New Racial Capitalism (Minneapolis: University of Minnesota Press, 2011), 139.

5. These are not necessarily temporal markers. An emergent formation or structure of feeling is not necessarily "new" in the sense that it has only just arrived. Instead, emergent cultural and social forms are those exhibited in the "practical consciousness" of the present moment that a "specifically dominant social order neglects, excludes, represses, or simply fails to recognize." Emergent, dominant, and residual formations are always present in any given cultural text. Raymond Williams, Marxism and Literature (Oxford: Oxford Paperbacks, 1978), 125.

6. I borrow the term "racial asymmetry" from Stephen Sohn. Stephen Hong Sohn, Racial Asymmetries: Asian American Fictional Worlds (New York: New York University Press, 2014).

7. Quoted in ibid., 36.

8. A. O. Scott, "Above It All," New York Times, March 14, 2004, sec. Books, https://www.nytimes.com/2004/03/14/books/above-it-all.html; "Fiction Book Review: Aloft by Chang-Rae Lee," Publishers Weekly, n.d., https:// www.publishersweekly.com/978-1-57322-263-1 (accessed July 6, 2017).

9. See also Patricia Chu, Assimilating Asians: Gendered Strategies of Authorship in Asian America (Durham, N.C.: Duke University Press, 2000).

10. Barbara Young Welke, Law and the Borders of Belonging in the Long Nineteenth Century United States (Cambridge: Cambridge University Press, 2010).

11. It is from this tension that Lowe derives her famous formulation of Asian American culture "as contradiction," that is, "as an alternative formation that produces cultural expressions materially and aesthetically at odds with the resolution of the citizen in the nation." Other critics, like Kandice Chuh and Jodi Kim, have built upon this essential foundation, declaring Asian American culture "an unsettling hermeneutic" and Asian American "a term in difference from itself" and a "designation of the (im)possibility of justice." See Lisa Lowe, Immigrant Acts: On Asian American Cultural 
Politics (Durham, N.C.: Duke University Press, 1996), 6; Chu, Assimilating Asians; Kandice Chuh, Imagine Otherwise: On Asian Americanist Critique (Durham, N.C.: Duke University Press, 2003), 8; Jodi Kim, Ends of Empire: Asian American Critique and the Cold War (Minneapolis: University of Minnesota Press, 2010), 10.

12. Melamed actually makes a historical distinction between "liberal multiculturalism," which for her characterizes the phase of multiculturalism that was hegemonic from the 1970s to the 1990s, and "neoliberal multiculturalism," which became hegemonic in the 1990s through the 2000s, culminating in the election of Barack Obama. Following Hong, Ferguson, and David Harvey, I do not necessarily delineate between these two phases, but use "neoliberal" to signal, broadly, the period from 1978 to the present. David Harvey, A Brief History of Neoliberalism (Oxford: Oxford University Press, 2007); Roderick A. Ferguson, The Reorder of Things: The University and Its Pedagogies of Minority Difference (Minneapolis: University of Minnesota Press, 2012); Grace Kyungwon Hong, The Ruptures of American Capital: Women of Color Feminism and the Culture of Immigrant Labor (Minneapolis: University of Minnesota Press, 2006); Melamed, Represent and Destroy.

13. Hong, Ruptures of American Capital, xx.

14. Ibid., 108; see also Melamed, Represent and Destroy; Aihwa Ong, Neoliberalism as Exception: Mutations in Citizenship and Sovereignty (Durham, N.C.: Duke University Press, 2006); Nikhil Singh, "Racial Formation in an Age of Permanent War," in Racial Formation in the Twenty-First Century, ed. Daniel HoSang, Oneka LaBennett, and Laura Pulido (Berkeley: University of California Press, 2012), 276-301.

15. See Lisa Duggan, The Twilight of Equality? Neoliberalism, Cultural Politics, and the Attack on Democracy (Boston: Beacon, 2004); Jasbir Puar, Terrorist Assemblages: Homonationalism in Queer Times (Durham, N.C.: Duke University Press, 2007); Chandan Reddy, Freedom with Violence: Race, Sexuality, and the US State (Durham, N.C.: Duke University Press, 2011).

16. Mark C. Jerng, "Nowhere in Particular: Perceiving Race, Chang-Rae Lee's Aloft, and the Question of Asian American Fiction," MFS Modern Fiction Studies 56, no. 1 (Spring 2010): 183-204.

17. Lee, Aloft, 364.

18. Karen Tongson, Relocations: Queer Suburban Imaginaries (New York: New York University Press, 2011), 13.

19. Sianne Ngai, Ugly Feelings (Cambridge, Mass.: Harvard University Press, 2007), 41, 43.

20. Arun Saldanha, "Reontologising Race: The Machinic Geography of Phenotype," Environment and Planning D: Society and Space 24 (2006): 20.

21. Singh, "Racial Formation," 291.

22. Jerng, "Nowhere in Particular," 194; Susan Koshy, "Morphing Race into Ethnicity: Asian Americans and Critical Transformations of Whiteness," Boundary 2 28, no. 1 (Spring 2001): 185. 
23. Matthew Frye Jacobson, Whiteness of a Different Color: European Immigrants and the Alchemy of Race (Cambridge, Mass.: Harvard University Press, 1999).

24. Ahmed frames orientation as a much broader theoretical concept in Queer Phenomenology, but I draw here on her narrower framing of race, and whiteness specifically, as an orientation. Sara Ahmed, "A Phenomenology of Whiteness," Feminist Theory 8, no. 2 (2007): 150; Sara Ahmed, Queer Phenomenology: Orientations, Objects, Others (Durham, N.C.: Duke University Press, 2006).

25. Melamed, Represent and Destroy, 152.

26. The distinction between "emergent" as a temporal marker and "emergent" as a cultural formation that is not always legible in the terms of the dominant cultural formation comes to the fore here. While multicultural neoliberalism may revise the avenues and strategies through which the boundaries and privileges of whiteness are extended, attempts from ethnic or racial minority groups to align themselves with whiteness are in no way new, as the work of Jacobson and David Roediger reveals. While whiteness studies has largely focused on how various European ethnic groups competed for and accomplished entree into whiteness during the late nineteenth and early twentieth centuries, Asian Americans themselves have had several public and legal contestations with the category of whiteness, as notably detailed by Susan Koshy. David R. Roediger, The Wages of Whiteness: Race and the Making of the American Working Class, new ed., ed. Mike Davis, Michael Sprinker, and Kathleen Cleaver (New York: Verso, 2007); Koshy, "Morphing Race into Ethnicity."

27. Lee, Aloft, 78.

28. Quoted in Sohn, Racial Asymmetries, 26.

29. Lee, Aloft, 78.

30. Ibid.

31. Ibid., 97.

32. Ibid., 128, 30, 218.

33. Ibid., 360.

34. Ahmed, "Phenomenology of Whiteness," 156.

35. Lee, Aloft, 215.

36. Ibid., 243.

37. Ibid., 212, 129 (emphasis original), 243.

38. Ahmed, "Phenomenology of Whiteness," 155.

39. Melamed, Represent and Destroy, 153.

40. Ibid., 108.

41. Ibid., 152.

42. Lee, Aloft, 218.

43. Yes, named for famed literary theorist Roland Barthes, whose signature area of study was semiotics, or the study of signs and signifiers. A joke about academics, perhaps-Theresa and Paul are subject to a number of these-or yet another self-conscious hint about the overdetermined nature of most of the symbols, locations, and signs in the novel. Ibid., 354. 


\section{-}

